\title{
Suggestions and Countermeasures of Financial System of Chinese Rural Compulsory Education
}

\author{
Yudong Hou \\ School of Economics, Wuhan University of Technology, Wuhan 430070, China
}

\begin{abstract}
The establishment of "County-level" rural compulsory educational financial system and the defects of it as well as the conduct of countryside compulsory education funds guarantee mechanism and its existing problems are worthy of attention for the current rural compulsory education. This article puts forward the corresponding countermeasures on the problems in the financial system for rural compulsory education to provide some reference recommendations for Chinese financial reform and improvement of rural compulsory education system.
\end{abstract}

Keywords: rural compulsory education; financial system; reconstruction strategy.

\section{Current Status of Rural Compulsory Education Financial System}

Financial system of Chinese rural compulsory education is mainly constituted by financial management system, the funding system and transfer payment system.

1.1 Financial Management System: The implementation of "county-level" management mode

Financial management system of rural compulsory education in China began in the mid-1980s. In 1985, "Decision on education reform" set by the CPC Central Committee points out the principle of implement of basic education by the local responsible management. With the implementation of tax, the rural tax and fee reform policy, the disadvantages of this system emerges.

The "County-level" of financial management system of rural compulsory education upgrades the global investment power from the village level to the district level on the global level. On the one hand, it advances the governmental investment body of rural compulsory education, on the other hand, it shifts financial responsibility for compulsory education in rural areas from farmers to the government. Specifically, in terms of education funding, teachers ' salaries and school renovation is bear by county or above levels of government. Public expense covering daily operations is both shared by county and township governments. The Central and provincial governments enhance the support capability of the financial difficulties of County funding for rural compulsory education by increasing transfer payments. "County-level" management system of rural compulsory education finance emphasizes the County Government is the one to bear the main responsibility for compulsory education in rural areas, which is a historic leap of the rural compulsory education management system [1].

\subsection{Financial Investment System: "Central and Local Governments Share" Mechanism}

Rural tax reform in 2000 cancelled the rural education additional fees and education funding accounting for around 30\% percent of total rural compulsory education investment. Government started building the long time safeguard mechanism of rural compulsory education funds relying on financial allocation.

On December 24, 2005, the State Council issued the announcement on deepening countryside compulsory education funds guarantee mechanism reform, which decided in a 5-year period from 2006 to take rural compulsory education into the scope of public finances gradually and establish a proportional share of new rural compulsory education funds guarantee mechanism according to central and local projects. First, the student tuition and fees are all exempt from compulsory education in rural areas and provide free textbooks and boarding cost of living for poor families. Secondly, public funding guarantee level for rural compulsory education should be improved in primary and secondary schools. Third, the establishment of long-term mechanism for primary and secondary schools maintenance and upgrading. Fourth, the teachers ' salaries guarantee mechanism in rural primary and secondary schools should be consolidated and improved. 


\subsection{Financial security system: the implementation of "special transfer" as the transfer payment system}

As the accessory system of rural compulsory education financial management, Chinese rural compulsory education transfer payment system for rural compulsory education was preliminarily established in the early 21st century. In this system, the "special transfer payments" focuses on support for rural compulsory education in poor rural areas in the Chinese Midwest. "Common transfer payments" is mainly used to balance education financial levels between different districts and committed to financial equity among regions leaning to rural areas in Central and Western regions.

After the reform of rural taxes and fees, Chinese government stepped up efforts to transfer payment for compulsory education in rural areas. Since 2001, the central fiscal sets 5 billion yuan annually as special transfer funds for covering rural primary and secondary school teaching and administrative staff salaries in Chinese Midwest. From 2001 to 2006, Central Government invested 9 billion yuan as special funds to the implementation of "national primary and secondary school buildings improvement project" and invested about 1.5 billion yuan yearly. Central Government sets up special funds "national compulsory education subsidies to poor students" and invests 100 million yuan every year since 2001 [2].

\section{Main Matters existing in Rural Compulsory Education Financial System}

\subsection{Overall inequality of rural compulsory education investment}

(1) Shortage of total compulsory education investment

Discussing whether the total government investment in rural compulsory education is adequate, the premise is to analyze the proportion of education in total government public investment. Financial education investment including State budget expenditure on education, taxes, fees charged by the government for education at all levels, enterprises funds, school-run industries, work-study funds and social services income for education, which is an important guarantee of the country's educational development and its scale reflects the country's emphasis on education. Because in a vast majority of countries, government investment in education is main source of national funding for education, so financial education funds can be on behalf of basic conditions and level of service of a national education. To measurement of the level of investment in education, it usually uses the proportion of fiscal educational expenditure in GDP (or GNP) internationally, as shown in table 1 below.

Tab.1 Proportion of Fiscal education investment in GDP and fiscal total expenditure in the 1990s.

\begin{tabular}{|c|c|c|c|c|}
\hline Year & $\begin{array}{c}\text { Fiscal education } \\
\text { expenditure(billion) }\end{array}$ & $\begin{array}{c}\text { Proportion of } \\
\text { fiscal education } \\
\text { investment in } \\
\text { GDP (\%) }\end{array}$ & $\begin{array}{c}\text { Proportion of fiscal } \\
\text { education investment } \\
\text { in budget in fiscal } \\
\text { expenditure (\%) }\end{array}$ & $\begin{array}{c}\text { Proportion of } \\
\text { fiscal income in } \\
\text { GDP (\%) }\end{array}$ \\
\hline 2000 & 2562.61 & 2.87 & 13.1 & 15.0 \\
\hline 2001 & 3057.01 & 3.19 & 11.7 & 16.8 \\
\hline 2002 & 3491.4 & 3.28 & 14.7 & 18.6 \\
\hline 2003 & 3850.62 & 3.32 & 14.8 & 18.5 \\
\hline 2004 & 4465.86 & 2.79 & 14.9 & 16.5 \\
\hline
\end{tabular}

(2) Low proportion of rural compulsory education investment in total investment

China is a large agricultural country and the rural population is high to 795.63 million accounting for $62.3 \%$ of the total population of the country and rural students account for the majority of students in total nationwide students. In 2003, for example, there are 54.7448 million people among national 66.1842 million junior students studying in the county town and rural schools, the proportion is $82.72 \%$ and the county town and the rural pupils are 98.8205 million among 116.8974 million in the country, which accounts for $84.54 \%$. For a long time, in all types of schools, compulsory education accounts for a low proportion of total investment and the students in compulsory education account for $78 \%$ of the total number of students in schools at all levels, but compulsory education investment proportion remains below $60 \%$ in total investment while the proportion of rural compulsory 
education investment to total investment is less than $40 \%$, therefore such funding is clearly unreasonable.

\subsection{County government finance rights and power is not unified, which cannot complete the comprehensive arrangement for funding in rural compulsory education with high quality.}

On one hand, from the perspective of power, as mentioned above, Chinese relevant laws and regulations stipulate the County Government responsibility for funding for compulsory education, establishing the "county-level" rural compulsory education finance management system and highlighting that the main responsibility should be bear by county-level governments the for compulsory education in rural areas. The other hand, the County Government's financial resources don't commensurate with their authority. First, quite a few counties in China, especially the predominantly agricultural County in the Midwest, weak financial capacity problems exist for a long time. Secondly, after the implementation of tax reforms, a larger change in Central and local fiscal revenues has been happened and county revenues decrease significantly. Third, after the rural tax and fee reform, fund raising and other extra charges of rural education are cancelled along with the fiscal revenue reducing of County and township level.

\subsection{Owing to the need to standardize and improve, transfer payment cannot make up for rural compulsory education funding gap}

From the transfer payment process, the general fiscal transfer payment for compulsory education are separate from the County, Township of basic needs in return and the annual transfer payment funds come into local budget revenue without determining the share of compulsory education to easily lead to embezzlement of education funds. According to the survey, in some places, transfer payment for compulsory education in rural areas from Central, 50\% are placed in provincial and municipal use, respectively [3].

From the transfer payment project, in many places, main education input channels namely financial education funds are still affiliated to rural finance and some County and township are always in one body. The reduced education funding by towns except for rural education surcharges can be supplemented by superior special transfer payments, but the other reduction projects mainly have no fixed supplement channels. Even the superior special transfer payments, it could not make up for the gaps of educational extra charges.

\section{Countermeasures of Rural Compulsory Education Financial System}

\subsection{Construction of a fair education financial management system}

Facing up to the reality of shortage of County government finance and ensuring finance supply of rural compulsory education, it needs to guarantee the funding responsibility of central, provincial and municipal government. The main content of "responsibility according to different area and level" financial management system includes following three aspects: first, on East, central, and West three class of area, initial source of the needed funding in rural compulsory education should be made to a reasonable division. Second, government financial responsibility should be divided again to make each level of government has unified property and powers. Third, provincial government should become the subject and leader of rural compulsory education financial funding investment. In particular, in 7 provinces and municipalities in the eastern part, it should adopt the rural compulsory education financial system to make county and province (municipality), the municipal government as the investment subjects and county-level governments bear the primary responsibility and financial gap should be supplemented by the provinces (municipalities), city levels of government. In the 12 provinces in the central region, it should make the central and provincial government investment be the subject in rural compulsory education management system and provincial governments bear the comprehensive arrangement responsibilities of rural compulsory education finance and funding gap should be filled by the central government. In the 12 provinces and autonomous regions in the western regions, it adopts the rural compulsory education financial system that the central and provincial governments share responsibility. 


\subsection{Enhancement investment in rural compulsory education and improvement of investment leader.}

Government funding is the main channel for education investment and current investment in compulsory education in rural areas is an important part of the whole education. In order to change the disadvantaged position of rural elementary education, it first should increase the national overall investment in education and all levels of government must fully implement the demand of investment responsibility from Compulsory Education Law and the Education Law. Along with economic development and revenue enhancement, it should increase investment in education. During budget arrangements, it should be in accordance with the proportion of educational investment in financial expenditure and proportion growth of compulsory education in financial education expenditure education to arrange the educational expenditure. At the same time, highlighting the absolute wealth status and role of government investment in rural compulsory education to increase the proportion of total government investment in compulsory education and prevent the governmental responsibility from transforming onto others and establish a theory of "Government responsible for People's education and build a real rural compulsory education investment protection mechanism [4].

\subsection{The construction of the standardized general transfer payment system}

In order to promote the balanced development of rural compulsory education, we need to establish a "level city revenue and expenditure gap" as the standard of transfer payment system of rural compulsory education. First, based on the lowest security line of national compulsory education funds, to prefecture level city as the basic unit, to determinate the rural compulsory education expenditure gap by calculating the standard expenditure and standard income of rural compulsory education funds in the region according to the factor method with the objective measurement of the economic model. Second, the municipal government finance of rural compulsory education expenditure gap is made up by the central, provincial government through the general transfer payment supplement. Third, according to the local economy development level, to determine the rural compulsory education finance sharing proportion and amount of the County and township governments. Fourth, the provincial government should take the main responsibility for the financial transfer payment of rural compulsory education. Specifically, the rural compulsory education finance of seven provinces and municipality in east area are in charge of the provincial and municipal governments. The share ratio is measured and set by the provincial government according to the level of GDP in the year and the financial revenue. While the other twelve provinces in the middle area, the rural compulsory education finance are in charge of central and provincial government. And the share ratio is measured and set by the same way with above-mentioned provinces in the east area. Correspondingly, the rural compulsory education finance of twelve provinces and Autonomous Region in the west area are in charge of the central governments. Provincial and prefecture level city government should also have the necessary funds. What's more, the provincial government should responsible for a majority of the funds.

\section{References}

[1]. Qiu Xiaojian. Current status, matters and countermeasures of rural economic compulsory financial system [J].Modern Education Management. 2009(11).

[2]. Gao Rufeng. Empirical analysis of the financial system in rural compulsory education in China [J]. Education Analysis, 2004,(5):1-6.

[3]. Tan Xilong. Existed Matters in rural basic education-example from Hubei Province [J]. Education Analysis and Experiment, 2006,(3):50-53.

[4]. Li Zhuyu. Current status and matters in Chinese compulsory education financial system [D]. Jiang Su: Nanjing Normal University, 2007. 